\title{
Peptidylarginine Deiminases and Protein Deimination in Skin Physiopathology
}

\author{
Shibo Ying ${ }^{1}$, Michel Simon², Guy Serre ${ }^{2}$ and Hidenari Takahara ${ }^{1}$ \\ ${ }^{1}$ Ibaraki University \\ ${ }^{2}$ CNRS-University of Toulouse III \\ IJapan \\ ${ }^{2}$ France
}

\section{Introduction}

Post-translational modifications of proteins are crucial because they may alter the physical and chemical properties, folding, distribution, stability, activity, and consequently the functions of the targets, some of which being involved into diseases. Recently, one of these post-translational modifications, deimination (also called citrullination), became of an increasing concern. It corresponds to the conversion of protein-bound arginine residues to citrulline residues in the presence of calcium ions (Figure 1). This modification dramatically alters the charge of residues from positive to neutral, probably resulting for the targets in loss of conformation, in aggregation ability, or in depolymerization tendency. Peptidylarginine deiminases (PADs, EC 3.5.3.15) have been found as the enzymes that catalyze deimination (Rogers and Taylor, 1977; Sugawara et al., 1982; Takahara et al., 1983). These enzymes belong to the family of hydrolases, those acting on carbon-nitrogen bonds other than peptide bonds, specifically in linear amidines.

Protein deimination has been demonstrated to be implicated in several skin physiological and pathological processes in human. PADs have long been suspected to be responsible for protein citrullination in the epidermis, as well as in some skin appendages, and their biological roles to be important. Thereby, there is an increasing interest about PAD research in dermatology and biomedicine. However, the molecular mechanisms controlling their expression and activity in human skin are still not fully understood.

In this chapter, we review PAD gene family, the regulation of their expression in keratinocytes, their known skin substrates, their physiological roles in the epidermis and skin appendages, and their associations with skin diseases. It is anticipated that these investigations will provide novel therapeutic and prophylactic targets for future approaches to the treatment or prevention of severe psoriasis and other skin diseases.

Peptidylarginine deiminases (PAD) hydrolyze arginine residues within proteins to create the non-native amino acid citrulline (see Figure 1, next page). Calcium ion is essential for the enzyme activation. Enzymatic deimination abolishes positive charges of native protein molecules, inevitably causing significant alterations in their structures and functions. 


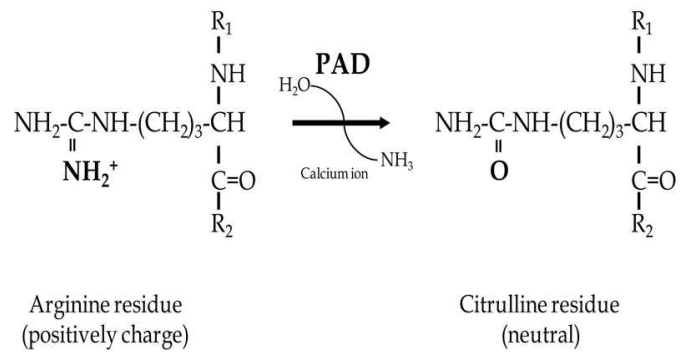

Fig. 1. Schematic representation of the deimination reaction catalyzed by a peptidylarginine deiminase.

\section{Peptidylarginine deiminase family}

Recently, vertebrate PADs were categorized into five isotypes, named PAD type I (PAD1), type II (PAD2), type III (PAD3), type IV (PAD4), and type VI (PAD6), based on their amino acid sequences, substrate specificities and tissue location (Chavanas et al., 2004; Méchin et al., 2005; Nachat et al., 2005a, 2005b). PAD4 has been previously designated as PAD5 (Vossenaar et al., 2003). Three isotypes are known in birds (Gallus gallus), whereas only one seems to exist in amphibians (Xenopus laevis) and fish (Danio rerio, Takifugu rubripes, Tetraodon nigroviris, and Oncorhynchus mykiss) (Vossenaar et al., 2003; Ying et al., 2009; Rebl et al., 2010). In mammals, all five isotypes of PADs have definitely been found in mouse (Mus musculus), rat (Rattus norvegicus) and human (Homo sapiens) (Terakawa, et al., 1991; Vossenaar et al., 2003). The five mammalian PADs are highly conserved at the amino acid sequence level with $59-71 \%$ of homology between human paralogs (45-55\% identity). In addition, the genes (named PADI) encoding each mammalian PAD type are clustered on single chromosomal locus, and they display the same exon/intron structure and a high nucleotide sequence homology in exons.

In human, all PADI genes are located at a single cluster which spans an about $334.7 \mathrm{~kb}$ region on the short arm of Chromosome 1 near the telomere (1p36.1). Conservation has been demonstrated at the levels of nucleotide sequences and organization of the human and murine PADI gene loci (Chavanas et al., 2004; Balandraud et al. 2005). Human PADs are proteins of 74.1-77.7 $\mathrm{kDa}$ predicted molecular mass (663-694 amino acids) with a rather acidic pI (4.97-6.15). Human PAD1 is mainly found in the epidermis and hair follicles. This isotype is involved in the late stages of epidermal differentiation. In corneocytes, it deiminates filaggrin and keratin $\mathrm{K} 1$, which maintains hydration of the stratum corneum, and hence the epidermal barrier function. This enzyme may also play a role in hair follicle formation (Chavanas et al., 2006). Human PAD2 enzyme is the most widely expressed family member (Ishigami et al., 2002, 2005). In particular, PAD2 is the only one among PAD isotypes to be expressed at a high level in central nervous system. Myelin basic protein, glial fibrillary acidic protein and vimentin are its known substrates. PAD2 is thought to play a role in the onset and progression of neurodegenerative human disorders, including Alzheimer disease and multiple sclerosis, and it has also been implicated in glaucoma pathogenesis (Bhattacharya et al., 2006; Moscarello et al., 2007; Cafaro et al., 2010). Human PAD3 modulates hair follicle structural proteins, such as trichohyalin and S100A3 in the 
inner root sheath (Rogers et al., 1997; Kanno et al., 2000; Kizawa et al., 2008). Together with the PAD1 enzyme, PAD3 may also play a role in terminal differentiation of the epidermis (Senshu et al., 1996; Méchin et al., 2007). Human PAD4 was first identified from the myeloid leukaemia cell line, HL-60 (Nakashima et al., 1999). It is normally found in the nucleus and in cytoplasmic granules of eosinophils and neutrophils. It has been reported to be involved in granulocyte and macrophage development leading to inflammation and the immune response (Wang et al., 2004). PAD4 is also expressed in rheumatoid arthritis synovial tissues (Vossenaar et al., 2003; Foulquier et al., 2007). Moreover, PAD4 is important for epigenetics, since the deimination of arginines and/or monomethylated arginines on histones 3 and 4 can act to antagonise arginine methylation (Kouzarides, 2007). Human PAD6, also known as ePad in mouse, was first identified in the year of 2004 (Chavanas et al., 2004). PAD6 mRNAs have been detected in ovary, testis, peripheral blood leucocytes, oocytes and early cleavage stage embryos (Chavanas et al., 2004; Esposito, et al., 2007; Yurttas, et al., 2008). However, the detail functions of PAD6/ePad are not well-known yet, even if it is essential for mouse fertility. Indeed, its absence induces an early zygote/embryo developmental defect (Esposito et al., 2007).

\section{Expression of peptidylarginine deiminases in human skin}

Although all PADI genes share significant identities at the level of their coding nucleotide sequences, the mechanisms responsible for their patterns of expression have been suspected to diverge. As described in section 2, each PADI gene has its own specific pattern of expression depending on the considered tissue, cell type or differentiation stage of the cells. Among the human PADs, only PAD1, PAD2 and PAD3 are expressed in the skin (Kanno et al., 2000; Ishigami et al., 2002; Guerrin et al., 2003). Here, we will sum up the actual findings on PAD expression in the human epidermis and skin appendages.

\subsection{Peptidylarginine deiminases in the epidermis}

Using RT-PCR experiments we have shown that only three PAD genes are expressed in human skin and epidermis at the mRNA level, namely the PADI1, 2 and 3 genes (Kanno et al., 2000; Ishigami et al., 2002; Guerrin et al., 2003). Messenger RNAs encoding PAD 4 and 6 are not detected in the normal tissue. Using anti-peptide antibodies specific for each isoform, we have confirmed this result at the protein level (Nachat et al., 2005a; Chavanas et al., 2006). Moreover, PAD1 is localized in the cytoplasm of keratinocytes throughout the whole human epidermis, with a higher expression in the granular layer, and in the corneocytes. PAD2 has been detected in the cytoplasm of the spinous keratinocytes and at the periphery of the granular ones, with a more intense staining of the latter. Anti-PAD3 antibodies have produced a punctate staining in the cytosol of the granular keratinocytes. PAD3 has also been observed in the matrix of the lower corneocytes, colocated with filaggrin, but could not be detected beyond the third or fourth corneocyte layer. Immunoelectron microscopy analyses have been used to specify the location at the ultrastructural level: PAD1 and PAD3 are located in the keratohyalin granules, together with profilaggrin, and in the fibrous matrix of the corneocytes together with filaggrin. PAD1 is also associated with the keratin intermediate filaments in the granular cells. Immunoblottings carried out on samples obtained from the superficial horny layer using adhesive tape stripping, confirmed that only PAD1 persists in the upper 
corneocytes, where keratins $\mathrm{K} 1$ and $\mathrm{K} 10$ are deiminated. Based on their biochemical properties and location within the fibrous matrix of the lower corneocytes, we have proposed PAD1 and PAD3 as the isoforms responsible for the deimination of filaggrin (Méchin et al., 2005; Nachat et al., 2005a; Chavanas et al., 2006). Therefore, PAD1 and 3 may participate in, and possibly control, the production of the amino acid components of the Natural Moisturizing Factor (NMF). In the upper cornified layer, the $\mathrm{NH}_{2}$ and $\mathrm{COOH}$-termini of keratins $\mathrm{K} 1$ and $\mathrm{K} 10$ are deiminated by PAD1 since it is the only PAD isoform detected there. In agreement, PAD1 is less sensitive than the other isoforms to a $\mathrm{pH}$ of 5.2, closed to the acidic $\mathrm{pH}$ of the upper stratum corneum (Méchin et al., 2007). The effect of keratin deimination is not really known, but it is concomitant with and therefore could be involved in the modifications of the intracorneocyte fibrous matrix observed at the ultrastructural level. In addition, PAD1 and/or PAD3 could be involved in the deimination of filaggrin-2, a recently described protein of the S100-fused type protein family that may participate in the formation of the NMF (Hsu et al, 2011). The epidermal targets and the function of PAD2 in the epidermis have not been identified so far.

\subsection{Peptidylarginine deiminases in skin appendages}

We have also been able to localize PADs in human skin appendages using the same specific antibodies (Nachat et al., 2005b). PAD1 has been observed, together with PAD2, in the secretory and myoepithelial cells of the sweat glands, and in the arrector pili muscles (Nachat et al., 2005b; Urano, et al.; 1990). However, no deiminated proteins have been detected in these appendages. For the moment, the role of PADs in cells of sweat glands and arrector muscles is completely unknown. So far, no PADs have been detected in human sebaceous glands.

PADs have also been detected in hair follicles in the anagen stage. PAD1 is expressed in the cytoplasm of keratinocytes in the concentric epithelial sheaths forming the hair follicles: first (starting from the hair bulb) the cuticle of the inner root sheath, then the Huxley's layer of the inner root sheath and finally the companion layer between the inner and the outer root sheaths. PAD3 is present within the inner root sheath and the medulla of the hair follicles. PAD3 has been shown to be perfectly colocalized with trichohyalin, which is the first protein shown to be deiminated. Trichohyalin is a major structural protein of cells in the inner root sheath and in the medulla of the hair shaft. Moreover, in vitro deimination by PAD3 of this alpha-helix-rich insoluble protein makes it more soluble and renders it available for efficient cross-linking by transglutaminase 3 (Tarca et al., 1997; Kanno et al., 2000). This strongly suggests that in vivo deimination by PAD3 allows trichohyalin to be solubilized from cytoplasmic granules where it is aggregated and then to be associated with hair keratins and other cornified cell components through covalent cross-links carried out by transglutaminases. Interestingly, some of these hair keratins, namely the inner root sheath-specific type-I keratin 27 and its mouse ortholog, are also deiminated before being cross-linked (Steinert et al., 2003). Therefore, PAD3 plays a major role in the establishment of the mechanical resistance of cells in the hair follicles and particularly in the hair shaft. PAD3 is also colocalized with S100A3, a calcium-binding protein of the S100 protein family supposed to be involved in hair cell differentiation. In vitro deimination by PAD3 of S100A3 at the Arg-51 promotes the assembly of a homotetramer, and increases its affinity for calcium ions (Kizawa et al., 2008). 


\section{Regulation of peptidylarginine deiminase expression in keratinocytes}

As the specific expression and distribution of PADs in human epidermis and skin appendages became clear, it appeared another question "how is the PAD gene expression controlled?" In fact, the PADI gene locus represents an interesting model to study the mechanisms which direct the spatial and temporal expression of genes in the epidermis. Indeed $P A D I$ gene expression is accurately regulated during the keratinocyte differentiation steps. PAD1 is detected throughout the epidermis with an increased expression in differentiated cells, PAD2 in the suprabasal layers, and PAD3 only in the terminally differentiated keratinocytes. Therefore PAD expression clearly depends upon the keratinocyte differentiation state. Until 2010, several original papers, shown in Figure 2 for a chronologic study, were published by our groups on PADI gene regulations at the transcriptional level.

These publications support the hypothesis of multiple DNA/transcription factor chromatin modules regulating PAD expression in normal human epidermal keratinocytes (NHEK), at the transcriptional level through a complex and original mechanism. The following sections will review what is known about the transcriptional regulation of PADI1-3 expression, remark the multiple regulatory modules, and highlight their significant features.

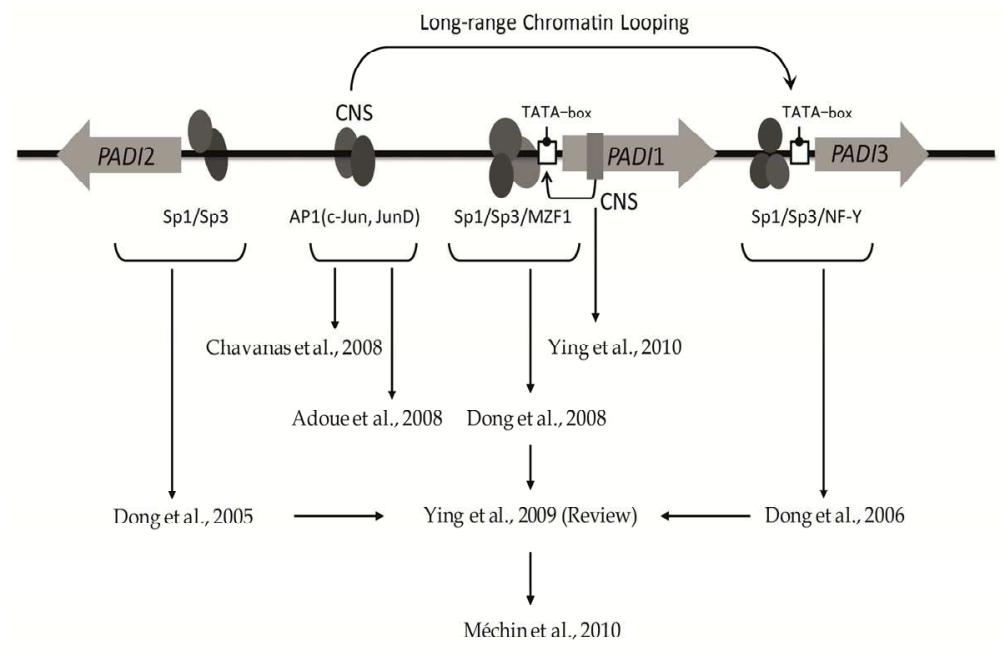

Fig. 2. History of transcriptional regulation of PADI1-3

Until 2010, the promoters of PADI1, 2 and 3, including the transcriptional factors and their binding sites, have been identified (Dong et al., 2005; Dong et al., 2006; Dong et al., 2008). Moreover, conserved non-coding sequences (CNSs) have been found in the PADI gene locus. They have been shown to contribute to long-distance transcriptional regulations of PADI1 and PADI3 promoters. One is an intronic enhancer located in the first intron of PADI1. Driven by NF-kB, it is able to enhance the PADI1 promoter activity (Ying et al., 2010). The other one located between PADI2 and PADI3 regulates PADI3 transcription by a long-range chromatin looping $(86-\mathrm{kb})$ during keratinocyte differentiation (Chavanas et al., 2008; Adoue et al., 2008). See detail in the text. Note that the scale is not respected. 


\subsection{Basal regulation of proximal promoters}

Proximal promoter elements are required for basal expression of all PADI1, 2 and 3 genes. The characterization of the PADI1-3 promoters has revealed several cis-elements for a number of distinct transcription factors. In the case of PADI1, chromatin immunoprecipitation (ChIP) assays have demonstrated that MZF1 and Sp1/Sp3 bind to its promoter region in vivo. Furthermore, either MZF1 or Sp1, but not Sp3, small interfering RNAs have effectively diminished the PADI1 expression in NHEK cultured in both lowand high-calcium containing medium (Dong et al., 2008). In addition, it also has been found that the expression of MZF1 and PAD1 increases synchronously during epidermal keratinocyte differentiation in vivo. Probably, MZF1 acts as an activator of the basic transcriptional activity, in response to the extracellular $\mathrm{Ca}^{2+}$ signaling cascades that lead to PADI1 expression during cell early differentiation (Dong et al., 2008). Although it lacks canonical TATA and CAAT boxes, the minimal promoter region of PADI2 contains some typical eukaryotic promoter elements, including four canonical GC boxes. Electrophoretic mobility-shift assays and super-shift analyses have demonstrated that both Sp1 and Sp3 actually bind to the GC boxes, and shown their marked involvement in the transcription regulation of PADI2. PADI3 proximal promoter has two CCAAT boxes, two GC boxes and a typical TATA box (Dong et al., 2005, 2006). Electrophoretic mobility-shift and ChIP assays have revealed that nuclear factor $\mathrm{Y}(\mathrm{NF}-\mathrm{Y})$ present in keratinocyte nuclear extracts actually bind the two CCAAT boxes, while Sp1/Sp3 bind the two GC boxes both in vitro and in vivo. Either deletion or site-directed mutagenesis of one of the CCAAT or GC boxes dramatically decreases the promoter activity (Dong et al., 2006). Furthermore, Sp1 or NF-YA (one of the three subunits of NF-Y) small interfering RNAs effectively diminish PADI3 gene expression in NHEK cultured in both low- and high-calcium medium. Therefore, both Sp1 and NF-Y are necessary for the expression of PADI3.

In the transcriptional regulation of PADI1, 2 and 3 in NHEK, Sp1/Sp3 is a common basic transcriptional factor. Sp-family of ubiquitous transcription activators is known to regulate the constitutive expression of a considerable number of genes, and to take part in virtually all aspects of cellular functions, including proliferation, apoptosis and differentiation (Kaczynski et al., 2003). Our results suggest that the ratio of Sp1 and Sp3 factors bound to the promoter of PADI genes is responsible for the basal regulation of PAD1-3 in the upper keratinocyte layers of the epidermis (Ying et al., 2009).

\subsection{Enhancer activity of conserved non-coding sequences}

Eukaryotic gene transcription is controlled not only by promoters but also by intragenic ciselements. More recently, a number of CNSs in vertebrate genomes have been shown to be transcriptional regulatory regions (Adams, 2005; Pennacchio, et al., 2006). Curiously, some highly conserved cis-regulatory regions are preferentially linked to developmental regulatory genes such as transcription factors and certain cell communication signals (Strähle \& Rastegar, 2008). Regarding to PADI genes, nineteen CNSs are clustered in an 8-kb region between $P A D I 1$ and $P A D I 2$. Interestingly, this region shows remarkable sequence conservation between several species, further suggesting its functional relevance (Chavanas et al, 2004). Subsequently, this region has been shown to contain a calcium responsive enhancer called CNS2 or PIE (for PAD intergenic enhancer segment), which dramatically triggers the activity of the PADI3 gene promoter upon epidermal keratinocyte 
differentiation, and links PADI3 expression to the AP-1 transcription factors c-Jun and JunD (Chavanas et al., 2008; Adoue et al., 2008). AP1 and Sp families have been suggested to play a central role in the regulation of epidermal gene expression during keratinocyte differentiation.

Moreover, except PADI6 gene, each of the human PADI genes contains a long first intron $(10-23 \mathrm{~kb})$, suggesting the first introns of these PADI genes are conserved during the speciation. In past, it has generally been assumed that the introns correspond to junk DNA without any function. More recently, however, this was disputed: more and more evidences revealed that introns are involved in transcriptional regulation and other functions (Eckert and Welter, 1996; Eckert et al., 1997). In particular, in silico analysis identified a conserved putative enhancer region within the first intron of PADI1. This region contains several consensus binding motifs for transcription factors, such as NF- $\mathrm{kB}$, ELK1 and CREL. Furthermore, ChIP results provided powerful evidence that both p50 and p65 NF-kB subunits directly bind to a cis-element (named CNSi) identified within the first intron of the PADI1 gene, and are critical for the in vivo expression of this gene via transcriptional regulatory mechanisms (Ying et al., 2010).

\subsection{Regulatory mechanism by an intra-chromatin loop}

Of great interest, chromosome conformation capture (3C) technique recently testified that distant enhancers co-localize and thus that chromatin has necessary to form loops to put them in contact within the nucleus (Dekker et al., 2002, 2006). The 3C technique has confirmed that the enhancer CNS2 described above, is physically close to the PADI3 gene promoter, thanks to a chromatin loop formation. Indeed, as shown in Figure 2, the enhancer is located $86 \mathrm{~kb}$ away from the PADI3 promoter (Chavanas et al., 2008; Adoue et al., 2008). Afterwards, $3 \mathrm{C}$ has also provided conclusive evidence for a potential interaction between the intronic CNSi, including the NF-kB cis-element, and the PADI1 gene promoter by way of chromatin looping (Ying et al., 2010). Long-range cis-elements are recently known as important regulators of gene transcription, particularly for paralogous genes clustered on a unique chromosomal region (for examples, see Ying et al., 2010). Such a contact between chromatin regions in calcium-stimulated keratinocytes suggests that intra-chromatin loopings govern the specific expression of PADI1 and 3 genes in a dynamic and united mechanism. Since long-range enhancers have been identified in a variety of other chromosomal regions distant from their cognate promoters and shown to be functional in keratinocytes (Carter et al. 2002; Li et al., 2002; Fraser, 2006; Bartkuhn et al., 2008), such a gene regulation at a distance might be a key feature in keratinocytes. These intrachromosomal chromatin loops constitute an important element in the architecture of the nucleus and in the regulatory control of a number of genes.

\subsection{Other modules}

Calcium ion has long been suspected as a major regulator of PADI genes at the transcriptional level. Similarly to the increased detection of PAD1-3 in the epidermis in the course of differentiation (Ying et al., 2009), the expression of PADI1-3 mRNAs is enhanced about two fold in NHEK cultured in $1.2 \mathrm{mM}$ calcium (differentiating conditions) as compared to $0.15 \mathrm{mM}$ (proliferating conditions). Local calcium ion concentrations could also regulate the subcellular localization of PADs, and their activity (Ying et al., 2009). In 
addition, high NHEK density increases PAD1 (threefold) and 3 (fivefold), but not PAD2, at the mRNA and protein levels, and up-regulates protein deimination (Méchin et al., 2010). By contrast, vitamin D increases PAD1-3 mRNA amounts, with distinct kinetics, but neither the corresponding enzymes nor the deimination rate (Méchin et al., 2010).

\section{Peptidylarginine deiminases in skin physiology and diseases}

As well-known, the skin provides a mechanical protection and is an important barrier for preventing the invasion of pathogens, the unintentional entrance of exogenous substances, and the uncontrolled loss of water and solutes (Madison, 2003). More and more evidence indicate that protein deimination and PADs are involved in several epidermal physiological and pathological processes. Thus, the identification of the targets of PADs is considered critical for advancing research on skin physiology and diseases.

\subsection{Deimination and peptidylarginine deiminases in skin physiology}

In human skin, all known substrates of PADs are cytoskeletal and cytoskeleton-associated proteins, crucial components for human skin homeostasis involved in forming rigid structures and keeping moisturizing of the horny layer. It has been found that filaggrin, filaggrin-2, keratin 1 (K1) and keratin 10 (K10) in the epidermis (Senshu et al., 1996; Kamata et al., 2009; Hsu et al, 2011), as well as trichohyalin and S100A3 in the hair follicles are the major deiminated proteins (Rogers et al., 1997; Tarcsa et al., 1996, 1997). The presence of deiminated proteins mainly in the stratum corneum suggests a function for deimination during cornification, the last steps of terminal differentiation of keratinocytes.

Deimination of filaggrin is a critical step in the production of a pool of amino acids necessary for the epidermal barrier functions (Kamata et al., 2009). Filaggrin is one of structural basic proteins found in abundance in the epidermis, and produced by the keratinocytes for organizing the keratin matrix. Filaggrin is synthesized by keratinocytes of the granular layer as a large precursor (400 kDa in human) called profilaggrin, an essential component of type F keratohyalin granules. During the granular keratinocyte to corneocyte transition, profilaggrin is proteolysed into filaggrin units. These histidine- and arginine-rich units associate with the keratin intermediate filaments facilitating their aggregation and the resulting formation of the intracorneocyte fibrous matrix. After its deimination in the stratum corneum, each filaggrin unit is thought to dissociate from the matrix and to be fully proteolysed to generate free amino acids of the NMF, a complex mixture of osmotic agents essential to maintain 10-15\% water in the stratum corneum (Rawlings \& Matts, 2005; Méchin et al., 2007; Kamata et al., 2009). The NMF is composed of glycerol, urea, lactate, ions and free amino acids (52\%), of which two derivatives have been characterized: pyrrolidone carboxylic acid and trans-urocanic acid. The amino acid content of NMF are nearly all produced from the degradation of filaggrin, their relative proportion being closely related to the filaggrin composition (Méchin et al., 2007; Simon et al., 2008; Kamata et al., 2009). However, filaggrin-2 degradation is strongly suspected to participate to the NMF formation (Hsu et al., 2011). Deimination of both filaggrin and filaggrin-2 increases the rate of their degradation by calpain 1 ad bleomycin hydrolases (Kamata et al., 20009; Hsu et al., 2011). Recently, non-sense mutations of the filaggrin gene have been defined as very strong predisposing factors for atopic dermatitis (OMIM 603165) and causative factors of ichtyosis 
vulgaris (OMIM 146700) (Irvine \& McLean, 2006; Palmer et al., 2006; Smith et al., 2006; Nomura et al., 2007; Sandilands et al., 2007). We have demonstrated the capacity of purified recombinant PADs to deiminate human filaggrin in vitro with different calcium and $\mathrm{pH}$ sensitivities according to the isotype of the used enzymes. These differences could regulate filaggrin deimination in vivo as calcium- and $\mathrm{pH}$-gradients are known to exist in the stratum corneum (Méchin et al., 2005, 2007). The exact role of keratin deimination is not well known. We can suspect an effect on the structure of the intracorneocyte filamentous matrix, or on their partial proteolysis in the upper part of the stratum corneum.

As mentioned in Section 3.2, trichohyalin is a structural protein of cells in the inner root sheath and in the medulla of the hair shaft. The deimination of trichohyalin catalyzed by PAD3 is crucial for the properties of trichohyalin, as well as for S100A3, another major protein of the hair follicles (Tarcsa et al., 1996, 1997; Steinert et al., 2003; Kizawa et al., 2008). Thereby, PAD3 is likely to play a major role in the establishment of the mechanical resistance of cells in the hair follicles and particularly in the hair shaft. However, the exact function of PAD1 and PAD2 in the hair follicles, including their targeted proteins, remains unknown.

\subsection{Deimination and peptidylarginine deiminases in skin diseases}

In recent years, more and more evidences suggested that the deimination and PADs are associated with skin diseases, especially with psoriasis. For example, decreased levels of keratin, in particular K1, deimination were observed in the epidermis of patients with bullous congenital ichthyosiform erythroderma (OMIM 113800) and psoriasis (OMIM 177900) (Ishida-Yamamoto, et al., 2000, 2002). Moreover, the PAD inhibitor paclitaxel, a well known molecule for cancer therapy, has been shown to improve severe psoriasis in a prospective phase II pilot study (Ehrlich et al., 2004). Furthermore, since vitamin D is beneficial in the treatment of psoriasis (Durakovic et al., 2004), it is tempting to speculate that the three PADs (PAD1, 2 and 3) expressed in the epidermis are possible therapeutic targets in the disease.

Interestingly, it is also thought that PADs might be involved in skin cancer. Indeed, PAD4 is abnormally expressed in some cutaneous cancers, as skin malignant melanoma (Chang et al., 2006, 2009). Especially, expression of PAD4 has been observed in some malignant tumors including skin carcinomas, with a concominant increased in deiminated keratins, and in extramammary Paget's disease (OMIM\#167300) (Urano et al., 1990; Chang et al., 2006, 2009). PAD4 expression is not detected in the corresponding human normal tissues. In agreement with the hypothesis of a possible involvement of PADs in tumorigenesis, inhibition or depletion, in osteosarcoma U2OS cells, of PAD4, the isotype responsible for the deimination of histones and involved in gene-expression regulation, has recently been shown to result in cell cycle arrest and apoptosis (Li, et al., 2008). So, PAD4 is becoming a target for an epigenetic cancer therapy (Slack et al., 2011). As a new finding, differential expression of the PADI1 gene has been claimed as a hallmark of squamous cell carcinomas of the oral cavity and oropharynx (Chen et al., 2008).

\section{Conclusion}

Nowadays, PADs are more and more considered as important in cellular physiology and human diseases. Over-expression of PAD and accumulation of citrullinated proteins could 
have a negative role. As we know, citrulline produced by PADs is a "non-natural" amino acid. Thereby, citrulline may stimulate the immune system and induce immune responses. More and more reports claim that citrullinated autoantigens are the possible cause of several autoimmune inflammatory diseases, including neurodegenerative disorders (multiple sclerosis and Alzheimer disease) and rheumatoid arthritis. Indeed, the current knowledge attests that multiple sclerosis is strongly linked to overcitrullination of the myelin basic protein (reviewed in Méchin et al., 2007). As another similar example, the patients with Alzheimer's disease have significantly elevated rate of citrullination (vimentin and glial fibrillary acidic protein) in their central nervous system, mainly in the hippocampus, which is the region of the brain mostly affected by the disease (Ishigami et al., 2005). Therefore PADs are now taken as potential drug targets.

Because of the description of their involvement in the late steps of keratinocyte terminal differentiation and the stratum corneum barrier functions, dermatologists are expected to take a great interest in these enzymes. In future, some approaches should provide new insight into PADI gene regulatory networks and discover the elaborate mechanisms of their signalling pathways upon cell dynamic state. More work is of great significance to definitively conclude on their contribution to skin diseases, especially in psoriasis and other inflammatory disorders.

\section{Acknowledgment}

The authors would like to thank all members of the Laboratory of Biochemistry and Molecular Biology of Ibaraki University (especially Prof. Toshio Kojima and Dr. Sijun Dong); and of the UMR5165 of the CNRS and Toulouse University (especially Dr. MarieClaire Méchin, Rachida Nachat, Stéphane Chavanas, Fanny Coudane and Véronique Adoue) for their contributions to the research discussed in this review. The authors' laboratories were supported in part by the Ministry of Education, Culture, Sports, Science and Technology of Japan, the French Society for Dermatology (SFD) and by Pierre Fabre Dermo-Cosmétique (Toulouse, France).

\section{References}

Adams, M.D. (2005) Conserved sequences and the evolution of gene regulatory signals. Current Opinion in Genetics \& Development, Vol.15, No.6 (December 2005), pp.628633, ISSN 0959-437X

Adoue, V.; Chavanas, S.; Coudane, F.; Méchin, M.; Caubet, C.; Ying, S.; Dong, S; Duplan, H.; Charveron, M.; Takahara, H.; Serre, G.; \& Simon, M. (2008). Long-range enhancer differentially regulated by c-Jun and JunD controls peptidylarginine deiminase-3 gene in keratinocytes. Journal of Molecular Biology, Vol.384, No.5, (December 2008), pp.1048-1057, ISSN 0022-2836

Balandraud, N.; Gouret, P.; Danchin, E.; Blanc, M.; Zinn, D. \& Roudier, J. (2005). A rigorous method for multigenic families' functional annotation: the peptidyl arginine deiminase (PADs) proteins family example. BMC Genomics, Vol.4, No.6, (November 2005), pp. 153, ISSN 1471-2164 
Bartkuhn, M. \& Renkawitz, R. (2008). Long range chromatin interactions involved in gene regulation. Biochimica et Biophysica Acta - Molecular Cell Research, Vol.1783, No. 11, (November 2008), pp. 2161-2166, ISSN 0167-4889

Bhattacharya, S.; Crabb, J.; Bonilha, V.; Gu, X.; Takahara, H. \& Crabb, J. (2006). Proteomics implicates peptidyl arginine deiminase 2 and optic nerve citrullination in glaucoma pathogenesis. Investigative Ophthalomolgy and Visual Sciences, Vol.47, No. 6 (June 2006), pp. 2508-2514, ISSN 0146-0404

Cafaro, T.; Santo, S.; Robles, L.; Crim, N.; Urrets-Zavalia, J. \& Serra, H. (2010) Peptidylarginine deiminase type 2 is over expressed in the glaucomatous optic nerve. Molecular Vision, Vol.16 (August 2010), pp. 1654-1658, ISSN 1090-0535

Carter, D.; Chakalova, L.; Osborne, C.; Dai, Y. \& Fraser, P. (2002). Long-range chromatin regulatory interactions in vivo. Nature Genetics, Vol.32, No. 6 (December 2002), pp. 623-626, ISSN 1061-4036

Chang, X. \& Han, J. (2006) Expression of peptidylarginine deiminase type 4 (PAD4) in various tumors. Molecular Carcinogenesis, Vol.45, No.3 (March 2006), pp. 183-196, ISSN 0899-1987

Chang, X.; Han, J.; Pang, L.; Zhao, Y.; Yang, Y. \& Shen, Z. (2009) Increased PADI4 expression in blood and tissues of patients with malignant tumors. BMC Cancer, Vol.9 (January 2009), pp. 40-51, ISSN 1471-2407

Chavanas, S.; Adoue, V.; Méchin, M.; Ying, S.; Dong, S.; Duplan, H.; Charveron, M.; Takahara, H.; Serre, G. \& Simon, M. (2008). Long-range enhancer associated with chromatin looping allows AP-1 regulation of the peptidylarginine deiminase 3 gene in differentiated keratinocyte. PLoS One, Vol.3, No. 10 (October 2008), e3408, ISSN 1932-6203

Chavanas, S.; Méchin, M.; Nachat, R.; Adoue, V.; Coudane, F.; Serre, G. \& Simon, M. (2006). Peptidylarginine deiminases and deimination in biology and pathology: Relevance to skin homeostasis. Journal of Dermatological Science, Vol.44, No.2, (November 2006), pp. 63-72, ISSN 0923-1811

Chavanas, S.; Méchin, M.; Takahara, H.; Kawada, A.; Nachat, R.; Serre, G. \& Simon, M. (2004). Comparative analysis of the mouse and human peptidylarginine deiminase gene clusters reveals highly conserved non-coding segments and a new gene, PADI6. Gene, Vol.330, No.1 (April 2004), pp. 19-27, ISSN 0378-1119

Chen, C.; Méndez, E.; Houck, J.; Fan, W.; Lohavanichbutr, P.; Doody, D.; Yueh, B.; Futran, N.D.; Upton, M.; Farwell, D.G.; Schwartz, S.M. \& Zhao, L.P. (2008) Gene expression profiling identifies genes predictive of oral squamous cell carcinoma. Cancer Epidemiology Biomarkers \& Prevention, Vol.17, No.8 (August 2008), pp. 2152-2162, ISSN 1055-9965

Dekker, J., Rippe, K., Dekker, M. \& Kleckner N (2002) Capturing chromosome conformation. Science. Vol.295, No.5558 (Febuary 2002), pp. 1306-1311, ISSN 0036-8075

Dekker, J. (2006), The three ' $\mathrm{C}$ ' s of chromosome conformation capture: controls, controls, controls. Nature Methods, Vol.3, No.1, ( January 2006), pp. 17-21, ISSN 1548-7091

Dong, S.; Kanno, T.; Yamaki, A.; Kojima, T.; Shiraiwa, M.; Kawada, A.; Méchin, M.; Chavanas, S.; Serre, G.; Simon, M. \& Takahara, H. (2006). NF-Y and Sp1/Sp3 are involved in the transcriptional regulation of the peptidylarginine deiminase type III gene (PADI3) in human keratinocytes. Biochemical Journal, Vol.397, No.3 (August 2006), pp. 449-459, ISSN 0264-6021 
Dong, S.; Kojima, T.; Shiraiwa, M.; Méchin, M.; Chavanas, S.; Serre, G.; Simon, M.; Kawada, A. \& Takahara, H. (2005). Regulation of the expression of peptidylarginine deiminase type II gene (PADI2) in human keratinocytes involves Sp1 and Sp3 transcription factors. Journal of Investigative Dermatology, Vol.124, No.5 (May 2005), pp. 1026-1033, ISSN 0022-202X

Dong, S.; Ying, S.; Kojima, T.; Shiraiwa, M.; Kawada, A.; Méchin, M.; Adoue, V.; Chavanas, S.; Serre, G.; Simon, M. \& Takahara, H. (2008) Crucial roles of MZF1 and Sp1 in the transcriptional regulation of the peptidylarginine deiminase type I gene (PADI1) in Human Keratinocytes. Journal of Investigative Dermatology, Vol.128, No.3 (March 2008), pp. 549-557, ISSN 0022-202X

Durakovic, C.; Ray, S. \& Holick, M.F. (2004) Topical paricalcitol (19-nor-1 alpha,25dihydroxyvitamin D2) is a novel, safe and effective treatment for plaque psoriasis: a pilot study. British Journal of Dermatology, Vol.151, No.1 (July 2004), pp. 190-195, ISSN 0007-0963

Eckert, R.L. \& Welter, J.F. (1996) Transcription factor regulation of epidermal keratinocyte gene expression. Molecular Biology Reports, Vol. 23, No.1 (January 1996), pp. 59-70, ISSN 0301-4851

Eckert, R.L.; Crish, J.F.; Banks, E.B. \& Welter, J.F. (1997) The epidermis: genes on - genes off. Journal of Investigative Dermatology, Vol.109, No.4 (October 1997), pp. 501-509, ISSN 0022-202X

Ehrlich, A.; Booher, S.; Becerra, Y.; Borris, D.L.; Figg, W.D.; Turner, M.L. \& Blauvelt, A.(2004) Micellar paclitaxel improves severe psoriasis in a prospective phase II pilot study. Journal of the American Academy of Dermatology, Vol.50, No.4 (April 2004), pp. 533540, ISSN 0190-9622

Esposito, G.; Vitale, A.M.; Leijten, F.P.; Strik, A.M.; Koonen-Reemst, A.M.; Yurttas, P.; Robben, T.J.; Coonrod, S. \& Gossen J.A. (2007) Peptidylarginine deiminase (PAD) 6 is essential for oocyte cytoskeletal sheet formation and female fertility. Molecular and Cellular Endocrinology, Vol. 273, No. 1, pp. 25-31, ISSN 0303-7207

Fraser, P. (2006) Transcriptional control thrown for a loop. Current Opinion in Genetics $\mathcal{E}$ Development, Vol. 16, No. 5 (October 2006), pp. 490-495, ISSN 0959-437X

Foulquier, C.; Sebbag, M.; Clavel, C.; Chapuy-Regaud, S.; Al Badine, R.; Méchin, M.-C.; Vincent, C.; Nachat, R.; Yamada, M.; Takahara, H.; Simon, M.; Guerrin, M. \& Serre, G. (2007) Peptidyl arginine deiminase type 2 (PAD-2) and PAD-4 but not PAD-1, PAD-3, and PAD-6 are expressed in rheumatoid arthritis synovium in close association with tissue inflammation. Arthritis and Rheumatism, Vol. 56, No.11 (November 2007), pp. 3541-53, ISSN 1529-0131

Guerrin, M.; Ishigami, A.; Méchin, M.; Nachat, R.; Valmary, S.; Sebbag, M.; Simon, M.; Senshu, T. \& Serre, G. (2003) cDNA cloning, gene organization and expression analysis of human peptidylarginine deiminase type I. Biochemical Journal, Vol.15, No.1 (February 2003), pp. 167-174, ISSN 0264-6021

Hsu, C.Y.; Henry, J.; Raymond, A.A.; Méchin, M.C.; Pendaries, V.; Nassar, D.; Hansmann, B.; Balica, S.; Burlet-Schiltz, O.; Schmitt, A.M.; Takahara, H.; Paul, C.; Serre, G. \& Simon, M. (2011) Deimination of human filaggrin-2 promotes its proteolysis by calpain 1. Journal of Biological Chemistry, Vol. 286, No.26 (July 2011), pp. 2322223233, ISSN 0021-9258 
Irvine, A.D. \& McLean, W.H. (2006) Breaking the (un)sound barrier: filaggrin is a major gene for atopic dermatitis. Journal of Investigative Dermatology, Vol.126, No.6 (June 2006), pp.1200-1202, ISSN 0022-202X

Ishigami, A.; Ohsawa, T.; Asaga, H.; Akiyama, K.; Kuramoto, M. \& Maruyama, N. (2002) Human peptidylarginine deiminase type II: molecular cloning, gene organization, and expression in human skin. Archives of Biochemistry and Biophysics, Vol.407, No.1 (November 2002), pp. 167-174, ISSN 0003-9861

Ishigami, A.; Ohsawa, T.; Hiratsuka, M.; Taguchi, H.; Kobayashi, S.; Saito, Y.; Murayama, S.; Asaga. H.; Toda, T.; Kimura, N. \& Maruyama N. (2005) Abnormal accumulation of citrullinated proteins catalyzed by peptidylarginine deiminase in hippocampal extracts from patients with Alzheimer's disease. Journal of Neuroscience Research, Vol. 80, No.1 (April 2005), pp.120-128, ISSN 0360-4012

Ishida-Yamamoto, A.; Eady, R.A.; Takahashi, H.; Shimizu, H.; Akiyama, M. \& Iizuka, H. (2002) Sequential reorganization of cornified cell keratin filaments involving filaggrin-mediated compaction and keratin 1 deimination. Journal of Investigative Dermatology, Vol.118, No.2 (February 2002), pp. 282-287, ISSN 0022-202X

Ishida-Yamamoto, A.; Senshu, T.; Takahashi, H.; Akiyama, K.; Nomura, K. \& Iizuka, H. (2000) Decreased deiminated keratin K1 in psoriatic hyperproliferative epidermis. Journal of Investigative Dermatology, Vol.114, No.4 (April 2000), pp. 701-705, ISSN 0022-202X

Kaczynski, J.; Cook, T. \& Urrutia, R. (2003) Sp1- and Krüppel-like transcription factors. Genome Biology, Vol.4, No.2 (November 2003), pp.206, ISSN 1474-760X

Kamata, Y.; Taniguchi, A.; Yamamoto, M.; Nomura, J.; Ishihara, K.; Takahara, H.; Hibino, T. \& Takeda, A. (2009) Neutral cysteine protease bleomycin hydrolase is essential for the breakdown of deiminated filaggrin into amino acids. Journal of Biological Chemistry, Vol.284, No.19 (May 2009), pp. 12829-12836, ISSN 0021-9258

Kanno, T.; Kawada, A.; Yamanouchi, J.; Yosida-Noro, C.; Yoshiki, A.; Shiraiwa, M.; Kusakabe, M.; Manabe, M.; Tezuka, T.; \& Takahara, H. (2000) Human peptidylarginine deiminase type III: molecular cloning and nucleotide sequence of the cDNA, properties of the recombinant enzyme, and immunohistochemical localization in human skin. Journal of Investigative Dermatology, Vol.115, No.5 (November 2000), pp. 813-823, ISSN 0022-202X

Kouzarides, T. (2007) Chromatin modifications and their function. Cell, Vol.128, No.4 (February 2007), pp. 693-705, ISSN 0092-8674

Kizawa, K.; Takahara, H.; Troxler, H.; Kleinert, P.; Mochida, U. \& Heizmann, C. (2008) Specific citrullination causes assembly of a globular S100A3 homotetramer: a putative $\mathrm{Ca}^{2+}$ modulator matures human hair cuticle. Journal of Biological Chemistry, Vol.283, No.8 (February, 2008), pp. 5004-5013, ISSN 0021-9258

Li, P.; Yao, H.; Zhang, Z.; Li, M.; Luo, Y.; Thompson, P.R.; Gilmour, D.S. \& Wang, Y.(2008) Regulation of p53 target gene expression by peptidylarginine deiminase 4 . Molecular and Cellular Biology, Vol.28, No.15 (August 2008), pp. 4745-4758, ISSN 0270-7306

Li, Q.; Peterson, K.R.; Fang, X. \& Stamatoyannopoulos, G. (2002) Locus control regions. Blood, Vol.100, No.9 (November 2002), pp. 3077-3086, ISSN 0006-4971

Madison, K.C. (2003) Barrier function of the skin: "la raison d'être" of the epidermis. Journal of Investigative Dermatology, Vol.121, No.2 (Augest 2003), pp.231-241, ISSN 0022-202X 
Méchin, M.; Coudane, F.; Adoue, V.; Arnaud, J.; Duplan, H.; Charveron, M.; Schmitt, AM.; Takahara, H.; Serre, G. \& Simon, M. (2010) Deimination is regulated at multiple levels including auto-deimination of peptidylarginine deiminases. Cellular and Molecular Life Sciences, Vol.67, No.9 (May 2010), pp.1491-1503, ISSN 1420-682X

Méchin, M.; Enji, M.; Nachat, R.; Chavanas, S.; Charveron, M.; Ishida-Yamamoto, A.; Serre, G.; Takahara, H. \& Simon M. (2005) The peptidylarginine deiminases expressed in human epidermis differ by their substrate specificities and subcellular locations. Cellular and Molecular Life Sciences, Vol.62, No.17 (September 2005), pp.1984-1995, ISSN 1420-682X

Méchin, M.; Sebbag, M.; Arnaud, J.; Nachat, R.; Foulquier, C.; Adoue, V.; Coudane, F.; Duplan, H.; Schmitt, A.; Chavanas, S.; Guerrin, M.; Serre, G. \& Simon, M. (2007) Update on peptidylarginine deiminases and deimination in skin physiology and severe human diseases. International Journal of Cosmetic Science, Vol.29, No.3 (June 2007), pp.147-168, ISSN 0142-5463

Moscarello, M.; Mastronardi, F. \& Wood, D. (2007) The role of citrullinated proteins suggests a novel mechanism in the pathogenesis of multiple sclerosis. Neurochemical Research, Vol.32, No.2, pp.251-256, ISSN 0364-3190

Nachat, R.; Méchin, M.; Takahara, H.; Chavanas, S.; Charveron, M.; Serre, G. \& Simon, M. (2005a) Peptidylarginine deiminase isoforms 1-3 are expressed in the epidermis and involved in the deimination of $\mathrm{K} 1$ and filaggrin. Journal of Investigative Dermatology, Vol.124, No.2 (February, 2005), pp.384-393, ISSN 0022-202X

Nachat, R.; Méchin, M.; Charveron, M.; Serre, G.; Constans, J. \& Simon, M. (2005b) Peptidylarginine deiminase isoforms are differentially expressed in the anagen hair follicles and other human skin appendages. Journal of Investigative Dermatology, Vol.125, No.1 (July, 2005), pp.34-41, ISSN 0022-202X

Nakashima, K.; Hagiwara, T.; Ishigami, A.; Nagata, S.; Asaga, H.; Kuramoto, M.; Senshu, T. \& Yamada, M. (1999) Molecular characterization of peptidylarginine deiminase in HL60 cells induced by retinoic acid and $1 \alpha$, 25-dihydroxyvitamin $\mathrm{D}(3)$. Journal of Biological Chemistry, Vol.274, No.39 (September 1999), pp.27786-27792, ISSN 0021-9258

Nomura, T.; Sandilands, A.; Akiyama, M.; Liao, H.; Evans, A.T.; Sakai, K.; Ota, M.; Sugiura, H.; Yamamoto, K.; Sato, H.; Palmer, C.N.; Smith, F.J.; McLean, W.H. \& Shimizu, H. (2007) Unique mutations in the filaggrin gene in Japanese patients with ichthyosis vulgaris and atopic dermatitis. Journal of Allergy and Clinical Immunology, Vol.119, No.2 (February 2007), pp.434-440, ISSN 0091-6749

Palmer, C.N.; Irvine, A.D.; Terron-Kwiatkowski. A.; Zhao, Y.; Liao, H.; Lee, S.P.; Goudie, D.R.; Sandilands, A.; Campbell, L.E.; Smith, F.J.; O'Regan, G,M.; Watson, R.M.; Cecil, J.E.; Bale, S.J.; Compton, J.G.; DiGiovanna, J.J.; Fleckman, P.; Lewis-Jones, S.; Arseculeratne, G.; Sergeant, A.; Munro, C.S.; El Houate, B.; McElreavey, K.; Halkjaer, L.B.; Bisgaard, H.; Mukhopadhyay, S. \&McLean, W.H. (2006) Common loss-of-function variants of the epidermal barrier protein filaggrin are a major predisposing factor for atopic dermatitis. Nature Genetics, Vol.38, No.4 (April, 2006), pp.441-446, ISSN 1061-4036

Pennacchio, L.A.; Ahituv, N.; Moses, A.M.; Prabhakar, S.; Nobrega, M.A.; Shoukry, M.; Minovitsky, S.; Dubchak, I.; Holt, A.; Lewis, K.D.; Plajzer-Frick, I.; Akiyama, J.; De Val, S.; Afzal, V.; Black, B.L.; Couronne, O.; Eisen, M.B.; Visel, A. \& Rubin 
E.M.(2006) . In vivo enhancer analysis of human conserved non-coding sequences. Nature, Vol.444, No.7118 (November 2006), pp.499-502, ISSN 0028-0836

Rawlings, A.V. \& Matts, P.J. (2005) Stratum corneum moisturization at the molecular level: an update in relation to the dry skin cycle. Journal of Investigative Dermatology, Vol.124, No.6 (June 2005), pp. 1099-1110, ISSN 0022-202X

Rebl, A.; Köllner, B.; Anders, E.; Wimmers, K. \& Goldammer, T. (2010) Peptidylarginine deiminase gene is differentially expressed in freshwater and brackish water rainbow trout. Molecular Biology Reports, Vol.37, No.5 (June 2010), pp.2333-2339, ISSN 0301-4851

Rogers, G.; Winter, B.; McLaughlan, C.; Powell, B. \& Nesci, T. (1997) Peptidylarginine deiminase of the hair follicle: characterization, localization, and function in keratinizing tissues. Journal of Investigative Dermatology, Vol.108, No.5 (May 1997), pp.700-707, ISSN 0022-202X

Rogers, G. \& Taylor, L. (1977) The enzymic derivation of citrulline residues from arginine residues in situ during the biosynthesis of hair proteins that are cross-linked by isopeptide bonds. Advances in Experimental Medicine and Biology, Vol.86A, (January 1977), pp.283-294, ISSN 0065-2598

Sandilands, A.; Terron-Kwiatkowski, A.; Hull, PR.; O'Regan, G.M.; Clayton, T.H.; Watson, R.M.; Carrick, T.; Evans, A.T.; Liao, H.; Zhao, Y.; Campbell, L.E.; Schmuth, M.; Gruber, R.; Janecke, A.R.; Elias, P.M.; van Steensel M.A.; Nagtzaam, I.; van Geel, M.; Steijlen, P.M.; Munro, C.S.; Bradley, D.G.; Palmer, C.N.; Smith, F.J.; McLean, W.H. \& Irvine, A.D. (2007) Comprehensive analysis of the gene encoding filaggrin uncovers prevalent and rare mutations in ichthyosis vulgaris and atopic eczema. Nature Genetics, Vol.39, No.5 (May, 2007), pp.650-654, ISSN 1061-4036

Senshu, T.; Kan, S.; Ogawa, H.; Manabe, M. \& Asaga, H. (1996) Preferential deimination of keratin $\mathrm{K} 1$ and filaggrin during the terminal differentiation of human epidermis. Biochemical and Biophysical Research Communications, Vol.225, No.3 (August 1996), pp.712-719, ISSN 0006-291X

Simon, M.; Takahara, H. \& Serre, G. (2008). Peptidylarginine deiminases, In: Skin Moisturization, Rawlings, A. \& Leyden, J. (Ed.), pp.69-82, Informa Healthcare, ISBN 142-007-0940, London, United Kingdom

Slack, J.L.; Causey, C.P. \& Thompson, P.R. (2011) Protein arginine deiminase 4: a target for an epigenetic cancer therapy. Cellular and Molecular Life Sciences, Vol.68, No.4 (February 2011), pp.709-720, ISSN 1420-682X

Smith, F.J.; Irvine, A.D.; Terron-Kwiatkowski, A.; Sandilands, A.; Campbell, L.E.; Zhao, Y.; Liao, H.; Evans, A.T.; Goudie, D.R.; Lewis-Jones, S.; Arseculeratne, G.; Munro, C.S.; Sergeant, A.; O'Regan, G.; Bale, S.J.; Compton, J.G.; DiGiovanna, J.J.; Presland, R.B.; Fleckman, P. \& McLean, W.H. (2006) Loss-of-function mutations in the gene encoding filaggrin cause ichthyosis vulgaris. Nature Genetics, Vol.38, No.3 (March, 2006), pp.337-342, ISSN 1061-4036

Steinert, P.M.; Parry, D.A. \& Marekov, L.N. (2003) Trichohyalin mechanically strengthens the hair follicle: multiple cross-bridging roles in the inner root shealth. Journal of Biological Chemistry, Vol.278, No.42 (Octomber 2003), pp.41409-41419, ISSN 0021-9258

Strähle, U. \& Rastegar, S. (2008) Conserved non-coding sequences and transcriptional regulation. Brain Research Bulletin, Vol.75, No.2 (March 2008), pp.225-230, ISSN 0361-9230 
Sugawara, K., Oikawa, Y. \& Ouchi, T. (1982) Identification and properties of peptidylarginine deiminase from rabbit skeletal muscle. Journal of Biochemistry, Vol. 91, No.3 (March 1982), pp.1065-1071, ISSN 0021-924X

Takahara, H., Oikawa, Y. \& Sugawara, K. (1983) Purification and characterization of peptidylarginine deiminase from rabbit skeletal muscle. Journal of biochemistry, Vol. 94, No.6 (December 1983), pp.1945-1953, ISSN 0021-924X

Tarcsa, E.; Marekov, L.; Andreoli, J.; Idler, W.; Candi, E.; Chung, S. \& Steinert, P. (1997) The fate of trichohyalin. Sequential post-translational modifications by peptidylarginine deiminase and transglutaminases. Journal of Biological Chemistry, Vol.272, No.44 (October 1997), pp. 27893-27901, ISSN 0021-9258

Tarcsa, E.; Marekov, L.; Mei, G.; Melino, G.; Lee, S.; \& Steinert, P. (1996) Protein unfolding by peptidylarginine deiminase. Substrate specificity and structural relationships of the natural substrates trichohyalin and filaggrin. Journal of Biological Chemistry, Vol.271, No.48 (November 1996), pp.30709-30716, ISSN 0021-9258

Terakawa, H.; Takahara, H. \& Sugawara, K. (1991) Three types of mouse peptidylarginine deiminase: characterization and tissue distribution. Journal of Biochemistry, Vol.110, No.4 (October 1991), pp. 661-666, ISSN 0021-924X

Urano, Y.; Watanabe, K.; Sakaki, A.; Arase, S.; Watanabe, Y.; Shigemi, F.; Takeda, K.; Akiyama, K. \& Senshu, T. (1990). Immunohistochemical demonstration of peptidylarginine deiminase in human sweat glands. American Journal of Dermatopathology, Vol.12, No.3 (June 1990), pp. 249-55, ISSN 0193-1091

Vossenaar, E.; Zendman, A.; van Venrooij, W. \& Pruijn, G. (2003) PAD, a growing family of citrullinating enzymes: genes, features and involvement in disease. BioEssays, Vol.25, No.11 (November, 2003), pp.1106-1118, ISSN 1521-1878

Wang, Y.; Wysocka. J.; Sayegh. J.; Lee, Y.H.; Perlin, J.R.; Leonelli, L.; Sonbuchner, L.S; McDonald, C.H.; Cook, R.G.; Dou, Y.; Roeder, R.G.; Clarke, S.; Stallcup, M.R.; Allis , C.D.; \& Coonrod, S.A. (2004) Human PAD4 regulates histone arginine methylation levels via demethylimination. Science. Vol. 306, No. 5694 (October 2004), pp. 279283, ISSN 0036-8075

Ying, S.; Dong, S.; Kawada, A.; Kojima, T.; Chavanas, S.; Méchin, M.; Adoue, V.; Serre, G.; Simon, M. \& Takahara, H. (2009) Transcriptional regulation of peptidylarginine deiminase expression in human keratinocytes. Journal of Dermatological Science, Vol.53, No.1 (January 2009), pp. 2-9, ISSN 0923-1811

Ying, S.; Kojima, T.; Kawada, A.; Nachat, R.; Serre, G.; Simon, M. \& Takahara, H. (2010) An intronic enhancer driven by NF- $\mathrm{kB}$ contributes to transcriptional regulation of peptidylarginine deiminase type I gene in human keratinocytes. Journal of Investigative Dermatology, Vol.130, No.11 (November 2010), pp.2543-2552, ISSN 0022-202X

Yurttas, P.; Vitale, A.M.; Fitzhenry, R.J.; Cohen-Gould L.; Wu, W.; Gossen, J.A. \& Coonrod, S.A. (2008) Role for PADI6 and the cytoplasmic lattices in ribosomal storage in oocytes and translational control in the early mouse embryo. Development, Vol. 135, No.15 (August 2008), pp. 2627-2636, ISSN 0950-1991 


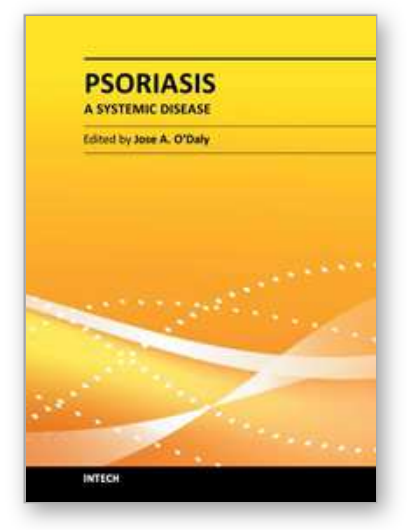

\author{
Psoriasis - A Systemic Disease \\ Edited by Dr. Jose O' Daly
}

ISBN 978-953-51-0281-6

Hard cover, 216 pages

Publisher InTech

Published online 16, March, 2012

Published in print edition March, 2012

The purpose of this book is to present a comprehensive analysis of Psoriasis, a disease that affects approximately $2-3 \%$ of humanity in all countries. Psoriasis existence is surveyed since the clay tablets of Assyrians and Babylonians 3.000-5.000 years ago, thru the middle ages, the renaissance, XIX and XX centuries.

\title{
How to reference
}

In order to correctly reference this scholarly work, feel free to copy and paste the following:

Shibo Ying, Michel Simon, Guy Serre and Hidenari Takahara (2012). Peptidylarginine Deiminases and Protein Deimination in Skin Physiopathology, Psoriasis - A Systemic Disease, Dr. Jose O' Daly (Ed.), ISBN: 978-95351-0281-6, InTech, Available from: http://www.intechopen.com/books/psoriasis-a-systemicdisease/peptidylarginine-deiminases-and-protein-deimination-in-skin-physiopathology

\section{INTECH}

open science | open minds

\author{
InTech Europe \\ University Campus STeP Ri \\ Slavka Krautzeka 83/A \\ 51000 Rijeka, Croatia \\ Phone: +385 (51) 770447 \\ Fax: +385 (51) 686166 \\ www.intechopen.com
}

\author{
InTech China \\ Unit 405, Office Block, Hotel Equatorial Shanghai \\ No.65, Yan An Road (West), Shanghai, 200040, China \\ 中国上海市延安西路65号上海国际贵都大饭店办公楼405单元 \\ Phone: +86-21-62489820 \\ Fax: +86-21-62489821
}


(C) 2012 The Author(s). Licensee IntechOpen. This is an open access article distributed under the terms of the Creative Commons Attribution 3.0 License, which permits unrestricted use, distribution, and reproduction in any medium, provided the original work is properly cited. 